\title{
Allogeneic leukocytes in cardiac surgery: Good or bad?
}

\author{
Kalp cerrahisinde allogeneik lökositler: İyi mi, kötü mü?
}

\author{
Yavuz M. Bilgin, Anneke Brand \\ Leiden University Medical, Department of Immunohematology and Blood Transfusion Center, and Sanquin \\ Bloodbank South West Region, Leiden, the Netherlands
}

\begin{abstract}
Worldwide, cardiac surgery is a common procedure requiring a large quantity of allogeneic blood products, which are associated with postoperative complications. Leukocytes present in blood products may play a role in these complications, which are referred to as transfusion-related immunomodulation (TRIM). Several randomized controlled trials (RCTs) in different settings investigated the effects of allogeneic leukocytes in red blood cells (RBCs). Cardiac surgery studies reported a reduction in postoperative infections and mortality in patients that received leukocyte-reduced RBCs compared with leukocyte-containing RBCs; this was mainly due to more deaths due to infections and multiple organ dysfunction syndrome (MODS) in the group that received leukocyte-containing RBCs. Patients with postoperative complications had higher concentrations of inflammatory mediators. These findings suggest that leukocytecontaining transfusion during cardiac surgery induces a second insult to the systemic inflammatory response. In the present review we discuss the possible role of blood transfusions in cardiac surgery. Especially, we focus on the possible role of allogeneic leukocytes associated with postoperative complications after cardiac surgery. (Turk J Hematol 2011; 28: 160-9)

Key words: Blood transfusions, transfusion-related immunomodulation, leukodepletion, infections, mortality, cardiac surgery

Received: December 30, $2010 \quad$ Accepted: April 18, 2011

Özet

Kalp cerrahisi, postoperatif komplikasyonlarla iliskilendirilen çok sayıda allogeneik kan ürünlerini gerektiren dünya genelinde yaygın bir girişimdir. Kan ürünlerinde bulunan lökositler, transfüzyon ile iliskili immünomodülasyon (TRIM) olarak adlandırılan bu tür etkilerde bir rol oynayabilir. Alyuvarlarda (RBC) allogeneik lökositlerin etkisinin araştırılması için farklı koşullarda çeşitli rasgele (randomize) kontrollü çalışmalar yapılmaktadır. Kalp cerrahisi çalışmalarında lökosit içeren RBC uygulanan hastalarda postoperatif enfeksiyonlar ve mortalitede maliyet etkinliği sağlayan bir azalma gösterilmiştir. Bu etkiler temelde enfeksiyonlar ve çoklu organ disfonksiyonu sendromuna bağlı daha fazla ölümden kaynaklanır. Postoperatif komplikasyonlu hastalarda enflamatuvar mediyatörler daha yüksek konsantrasyonlarda mevcuttur. Bu bulgular kalp cerrahisi sırasında lökosit içeren transfüzyonların sistemik enflamatuvar yanıta bağlı bir hasara neden olduğunu düşündürmektedir. Bu incelemede kalp cerrahisinde allogeneik lökositlerin olası rolleri ele alınmaktadır. Allogeneik lökositlerin rolünün anlaşılabilmesi için olası mekanizmalar önerilmektedir. (Turk J Hematol 2011; 28: 160-9)

Anahtar kelimeler: Kan transfüzyonları, transfüzyon ile ilişkili immünomodülasyon, lökodeplesyon, enfeksiyonlar, mortalite, kardiyak cerrahisi
\end{abstract}

Geliş tarihi: 30 Aralık 2010

Kabul tarihi: 18 Nisan 2011

Address for Correspondence: Yavuz M. Bilgin MD, Erasmus Medical Center, Department of Hematology, Postbus 5201, 3008 AE Rotterdam, the Netherlands Phone: +31 107033123 Fax: +31 107035814 E-mail: bilginyavuz@hotmail.com 


\section{Introduction}

Allogeneic blood transfusions are administered to control acute bleeding and to treat severe anemia. Regarding transmission of infections in wellsourced countries, blood transfusion is safer than ever, although blood transfusion will be a never zero-risk procedure [1]. Coronary artery bypass graft (CABG) surgery is frequently performed for revascularization of the myocardium. Worldwide, approximately 1,000,000 patients undergo cardiac surgery annually. Currently, the number of elderly patients, including those with co-morbidity, that undergo surgery is increasing. Due to bleeding, hemodilution, and consumption of coagulation factors and platelets in the extracorporeal circuit patients undergoing cardiac surgery receive a large quantity of blood components. With the advent of blood-sparing procedures the need for blood transfusions has been reduced; however, cardiac surgery still consumes a large proportion of all red blood cell (RBC) transfusions, estimated to be approximately $20 \%$ of the total blood supply [2]. The transfusion rate for $\mathrm{CABG}$ varies greatly between hospitals, with a mean number of transfused units ranging from 0.4 to 6.3 units patient ${ }^{-1}[3,4]$.

The clinical effects of blood transfusion in cardiac surgery remains contentious. In the last decade clinical studies have focused on the indications for transfusion, storage of blood products, and leukocytes in blood products in an effort to improve the safety of blood transfusion. The present review concentrates on the effects of blood transfusion in patients undergoing cardiac surgery.

The Effects of the Indications for RBC Transfusion For decade's a hemoglobin ( $\mathrm{Hb}$ ) level of $10 \mathrm{~g} / \mathrm{dL}$ (6.2 $\mathrm{mmol} / \mathrm{L})$ was considered an appropriate indication for RBC transfusion [5]. A randomized controlled trial (RCT) performed in the 1990s challenged the classical RBC transfusion policy [6], resulting in a tendency for a lower $\mathrm{Hb}$ level as an indication [7]. In this large-scale RCT that included 838 patients in an intensive care unit (ICU), the patients were either transfused to maintain an $\mathrm{Hb}$ value $7-9 \mathrm{~g} / \mathrm{dL}$ (restrictive) or $>10 \mathrm{~g} / \mathrm{dL}$ (liberal). Patients assigned to the restrictive indication group received a mean 2.6 units of RBCs, compared to a mean 5.6 units in the liberal indication group. Mortality at $30 \mathrm{~d}$ the primary outcome measure did not differ significantly between the groups, which was $18.7 \%$ and $23.3 \%$ in the restrictive and liberal indication groups, respectively (OR: $0.80 ; 95 \% \mathrm{CI}$ :
0.61-1.04 [p=0.11]). Among the subgroups of patients $<55$ years of age and those with a low APACHE (Acute Physiology And Chronic Health Evaluation) risk score, mortality was significantly lower in the restrictive indication group than in the liberal indication group $(5.7 \%$ versus $13 \%[p=0.02]$ and $8.7 \%$ versus $16.1 \%$ [ $p=0.03$, respectively) [6].

A recent cardiac surgery RCT that included 502 patients reported that a more restrictive RBC strategy based on a hematocrit of $24 \%$ is as safe as a liberal RBC strategy based on a hematocrit of 30\%; 30-d mortality and morbidity were approximately $10 \%$ in both groups [8]. Since the implementation of universal leukodepletion of RBCs in several countries, 2 observational studies reported that allogeneic blood transfusion was not associated with high mortality rates, but instead, highHb concentrations and receipt of blood transfusions were associated with lowmortality rates $[9,10]$; however, this finding has yet to be confirmed by RCTs.

\section{The Effects of RBC Storage}

During storage RBCs undergo a number of structural and functional alterations, referred to as storage lesions. Changes in shape, rigidity, depletion of 2,3-diphosphoglycerate (2,3 DPG), and nitric oxide scavenging are presumed to result in impaired perfusion and oxygen delivery [11,12]. The clinical effects have only been evaluated in observational studies in different clinical settings, and the results were inconclusive. Several retrospective cardiac surgery studies investigated RBC storage duration [13-17], but the findings were inconsistent. A recent cardiac surgery observational study investigated the effects of peri-operative transfusion of RBCs stored $<14 \mathrm{~d}$ or $>14 \mathrm{~d}$ [18]. The study reported that the 1 -year mortality rate was higher in patients that received $\mathrm{RBCs}$ stored $>14 \mathrm{~d}$; however, the association between storage duration and mortality was based only on unadjusted analysis. Identifying confounders were not adjusted for RBC storage duration, which led to several letters in response [19]. Because different blood products and storage durations were used, meta-analysis could not be used to formulate a reliable consensus on the possible association between RBC storage duration, and morbidity and mortality [20]. As such, results from prospective studies are needed.

\section{Allogeneic Leukocytes in RBC Products}

Allogeneic RBC transfusion has profound effects on the recipient's immune system. This immunomodulatory effect of blood transfusion, presumed to 
be due to allogeneic leukocytes, was first recognized in the 1970s in kidney allograft patients in whom pre-transplant blood transfusion improved allograft survival [21]. In the 1980s it was suggested that such immune suppression could cause cancer recurrence and postoperative infections [22]. These possible adverse effects of blood transfusion are referred to as transfusion-related immunomodulation (TRIM) and the mechanisms of TRIM are not fully understood. Many clinical and laboratory studies investigated the possible immunomodulatory effects and mechanisms of TRIM, and several factors have been suggested to play a role. The most commonly suspected factors are allogeneic mononuclear cells, soluble biological response modifiers circulating in plasma, and leukocyte-derived mediators. Allogeneic leukocytes or soluble factors released by leukocytes during storage have been extensively studied in recent years [23]. Because allogeneic leukocytes are the most important factor thought to be responsible for the clinical effects of TRIM, RCTs investigating their role are indispensable. In an effort to investigate the clinical effects of TRIM several studies compared leukocyte-containing and leukodepleted blood products in different clinical settings. Two RCTs compared the effects of buffy coatpoor RBC and filtered RBC on cancer recurrence following colorectal surgery performed with curative intent. Both studies evaluated long-term outcome after 5 and 7 years of follow-up and did not observe a difference in colorectal cancer recurrence [24-26]. Several RTCs investigated the effect of leukocyte-containing blood transfusion on postoperative infections, primarily in colorectal surgery.

Before the 2000s only selected patients received leukodepleted transfusions for the prevention of HLA alloimmunization, cytomegalovirus (CMV) transmission (or reactivation), and febrile nonhemolytic transfusion reactions (FNHTR) due to cytokines or leukocyte antibodies present in the patient. Since 2002, all patients in the Netherlands that require transfusion receive leukodepleted blood transfusions. In the last decennium last years more countries in the Western World implemented universal leukodepletion for RBCs. Countries that have not yet converted to universal leukodepletion that seek a new policy should base their decision on the available RTC data.

\section{The Clinical Effects of Allogeneic Leukocytes in Cardiac Surgery}

On average, more patients receive allogeneic blood transfusions during cardiac surgery than in other clinical settings. Several observational studies on cardiac surgery reported that perioperative administration of blood products is dose-dependently associated with increases in the incidence of postoperative infections and mortality [27]. Observational studies observed that RBC transfusion was the most consistent factor associated with mortality and morbidity [28,29]; however, these were retrospective studies and therefore provide no proof of the causal effect of allogeneic RBC transfusion on postoperative morbidity and mortality after cardiac surgery, in which many factors influence outcome; to date, this association is not fully understand. Compared to other unexpected adverse transfusion effects, the clinical effects of leukocyte-mediated TRIM on mortality following cardiac surgery are more well-known [30]; therefore, the role of TRIM in cardiac surgery requires further study in order to increase our understanding of the effects of allogeneic leukocytes on postoperative complications and outcome. As allogeneic leukocytes are the most important factor associated with the clinical effects of TRIM, RCTs investigating their role followed.

Four cardiac surgery RCTs have been published [31-34] and 2 other cardiac surgery studies are available only as abstracts and contain limited data $[35,36]$. The primary methods and results are shown in the Table 1. Two of these trials randomized patients to receive 3 different blood products. One of the studies compared buffy coat-depleted (BCD)RBCs and 2 different filtered RBCs fresh filtered RBCs before storage (FF-RBCs) or stored filtered RBCs (SF-RBCs) [31]. All products had a similar shelf life of about $13 \mathrm{~d}$. The 60 -d mortality rate was $7.8 \%$ in the group that received BCD-RBCs, as compared to $3.6 \%$ and $3.3 \%$ in those that received FF-RBC and SF-RBC products, respectively $(p=0.015)$. This suggests that soluble mediators still present in the SF-RBC products did not cause more adverse effects than FF-RBCs that lacked leukocyte-derived soluble factors. Subgroup analysis showed that the mortality rate was only higher in the patients that received $>3$ $\mathrm{RBC}$ units in the BCD-RBC group than in the filtered RBC group. Wallis et al. [32] conducted a study using 3 types of blood products: filtered whole blood (stored $<7 \mathrm{~d}$ before filtration), BCD-RBC, and plasma-reduced RBCs. Postoperative mortality at 3 months was $0.5 \%, 2.9 \%$, and $2.5 \%$, respectively $(\mathrm{p}=0.2)$, indicating no additional deleterious effect of the greater number of leukocytes in plasmareduced RBCs, as compared to BCD-RBCs [32]. van 
de Watering et al. [31] observed that mortality due to multiple-organ-dysfunction-syndrome (MODS) was the major cause of excess death following standard BCD-RBC transfusion. Bilgin et al. studied complex cardiac valve surgery, which has a high probability of multiple RBC transfusions and a high risk for postoperative complications. The aim was to examine the relationship between leukocyte-containing transfusion, and MODS and mortality [33]. The primary endpoint 90-d mortality was (not significantly) reduced by approximately $33 \%$ in the patient group that received leukocyte-depleted RBCs, as compared to the group that received BCD-RBCs $(12.7 \%$ versus $8.4 \%, p=0.16)$. Hospital mortality in the leukocyte-depleted RBC group was almost $50 \%$ less than that in the BCD-RBC group (5.5\% versus $10.1 \%$, $\mathrm{p}=0.05)$. Surprisingly, in this study the incidence of MODS (20\%) was similar in the groups that received standard BCD-RBCs and pre-storage filtered RBC; however, MODS-related death occurred more often in patients that received BCD-RBCs. Subgroup analysis showed that among the patients that received BCD-RBCs, only those that received $>3$ units had a higher mortality rate $(17.6 \%$ versus $8.3 \%, \mathrm{p}=0.02)$. A small-scale study that included 69 low-risk CABG patients compared bedside-filtered RBCs (containing soluble leukocyte-produced factors) and the same unfiltered RBC product [34]. There was no difference in mortality between both randomized arms. This study was stopped prematurely because interim analysis showed that there were fewer respiratory tract infections in the filtered group $(p=0.048)$, although the total infection rate did not differ $(p=0.22)$. When the results of cardiac surgery RCTs were meta-analyzed, the mortality rate increased to $72 \%$ in patients that received leukocyte-containing RBCs (OR: 1.72; 95\% CI: 1.05-2.81, $\mathrm{p}=0.01$ ) [37]; the difference between leukocytecontaining and filtered group was primarily due to the results of the 2 studies from the Netherlands $[31,33]$. It should be noted that these large studies were comparable and were conducted with patients associated with a high risk for postoperative complications and multiple RBC transfusions. As not all studies have been published in full (some are only available as an abstract), at present, data are 1 imited. Moreover, some (undocumented) differences in the use and preparation of blood products and in endpoints between studies may be why the findings vary.
It was reported that the number of units transfused not the soluble mediators leukocytes release during storage [31] or the leukocyte load per transfusion [32] is associated with poor outcome [31,33], suggesting that patients in poor clinical condition that undergo cardiac surgery and require multiple RBC transfusions are more susceptible to TRIM than other patients. We analyzed in detail the causes of death in 2 cardiac surgery RCTs [31,33] and observed that the rate of excessive death due to a combination of infection and MODS among the patients that received standard buffy coat-poor RBCs was higher than that among the patients that received leukodepleted FF-RBCs (OR 2.92; 95\% CI 1.22-6.97; $\mathrm{p}=0.02$ ). Short-term mortality (60 d) due to infections alone and from MODS alone, or due to bleeding or surgical complications was equal in both transfusion arms [38]. Although in cardiac surgery patient longterm survival is negatively affected by allogeneic blood transfusions, as compared to non-transfused patients [39], the long-term effects of allogeneic leukocytes in RBCs after cardiac surgery are not known and require further study.

In total, 13 RCTs on leukodepleted blood transfusions in different clinical settings evaluated postoperative infections as a primary or secondary endpoint [31-36,40-46]. These studies included singleand multicenter designs, clinical diagnosis, methods for documenting and reporting infections, and the proportion of transfused patients (range: 14\%95\%). Among them, 5 included patients undergoing colorectal or gastrointestinal surgery [40-44], 1 was performed with patients undergoing aortic aneurysm repair or resection of gastrointestinal malignancy [45], and 1 included trauma patients [46]. The postoperative infection results in these RCTs, which were conducted with different patient populations using different study designs, are inconsistent. Based on intention-to-treat analysis, Vamvakas concluded that there wasn't an association between leukocyte-containing transfusions and the incidence of postoperative infection [37]. Blumberg et al. analyzed subgroups of transfused patients only, excluding $36 \%$ of the patients, and concluded that there was a significant and clinically relevant $48 \%$ reduction in the postoperative infection rate following transfusion of leukocyte-depleted RBCs [47]. Due to the heterogeneity of the study designs and the types of blood products used in these RCTs, an overall consensus could not be made, not even based on meta-analysis of the studies. Postoperative infection was examined in 6 cardiac surgery RCTs and the 
results were inconsistent [31-36]. Two RCTs reported a transfusion dose-dependent beneficial effect of leukocyte-depleted RBCs [31,33], 3 reported no benefit from leukocyte-depleted RBCs [32,35,36], and 1 RCT showed only benefit from leukocyte-depleted RBCs in the incidence of pneumonia [34]. The characteristics and main results of these cardiac surgery RCTs are shown in the Table 1. How postoperative infections was defined in the studies published only as abstracts is not mentioned; this was not different in the studies that were fully published.

Analyses on the cost-effectiveness of leukodepletion are scarce and are mainly based on observational data. The available data show that there is a benefitinselectedpatientpopulations. Leukodepletion of whole blood was associated with lower hospital costs than leukocyte-containing blood transfusions in colorectal surgery [48] and that leukodepletion of platelets was beneficial in the treatment of acute myeloid leukemia and lymphoma [49]. The costeffectiveness of cardiac surgery was analyzed based on data derived from 2 studies performed in the Netherlands [31,33]. The results showed that RBC leukodepletion was cost effective. The benefit of leukodepletion of RBCs was between $\$ 220$ - $\$ 310$ US per life-year gained in CABG patients [50] and \$214 US per cardiac valve surgery patient, on average [51].
Because most West European countries have implemented universal leukodepletion, new RCTs from these countries are not expected. As such, observational studies were performed to compare the incidence of complications before and after this implementation. One large multicenter study that included critically ill patients (including cardiac surgery patients) reported a reduction in hospital mortality and a decrease in the occurrence of fever and use of antibiotics after implementation of universal leukodepletion [52]. Despite the large number of studies, leukocyte-containing RBCs remains controversial.

During cardiac surgery RBCs are not the only transfused blood product used. A substantial proportion of patients also receive plasma and platelet transfusions. Plasma transfusions can contribute to adverse outcome by causing transfusion-related acute lung injury (TRALI), a serious life-threatening and underreported complication of allogeneic blood transfusions. The pathophysiology of TRALI is not fully understood; all plasma-containing blood products could be involved in the development of TRALI [53]. It has been suggested that platelet transfusions in cardiac surgery might be associated with postoperative complications. Whether or not platelet and plasma transfusions contribute to such postoperative complications, or are just a surrogate marker for the need for a higher number of RBC transfusions

Table 1. Comparison of RTCs that included patients transfused with leukodepleted and leukocyte-containing RBCs

\begin{tabular}{|c|c|c|c|c|c|c|c|}
\hline Study & $\begin{array}{l}\text { No. of Patients/ } \\
\text { No. transfused } \\
(\%)\end{array}$ & $\begin{array}{l}\text { Clinical } \\
\text { Setting }\end{array}$ & $\begin{array}{c}\text { Transfused } \\
\text { Patients }\end{array}$ & $\begin{array}{l}\text { Units of RBCs } \\
\text { (mean } \pm \text { SD } \\
\text { or median) }\end{array}$ & $\begin{array}{c}\text { Main } \\
\text { Endpoints }\end{array}$ & Results $^{b}$ & $\mathbf{P b}$ \\
\hline $\begin{array}{l}\text { van de Watering } \\
\text { et al. } 1998 \text { [31] }\end{array}$ & $914 / 866$ (95) & $\begin{array}{l}\text { CABG } \pm \text { valve } \\
\text { surgery }\end{array}$ & $\begin{array}{c}\text { FF } 283 \\
\text { SF } 280 \\
\text { BCD } 303\end{array}$ & $\begin{array}{c}\text { FF } 5.3 \pm 4.1 \\
\text { SF } 5.5 \pm 5.6 \\
\text { BCD } 5.4 \pm 5.1\end{array}$ & $\begin{array}{l}\text { 1) Infections } \\
\text { 2) } 60 \text {-d mortality }\end{array}$ & $\begin{array}{l}\text { 1) } 17.3 \% \text { vs } 23.0 \% \\
\text { 2) } 3.5 \% \text { vs. } 7.8 \%\end{array}$ & $\begin{array}{l}\text { 1) } 0.13 \\
\text { 2) } 0.01\end{array}$ \\
\hline $\begin{array}{l}\text { Bracey et al. } \\
2002[35]^{a}\end{array}$ & $357 / 295$ (83) & $\begin{array}{l}\text { CAGB } \pm \text { valve } \\
\text { surgery }\end{array}$ & $\begin{array}{l}\text { LD } 136 \\
\text { BCC } 159\end{array}$ & $\begin{array}{c}\text { LD } 3 \\
\text { BCC } 3\end{array}$ & $\begin{array}{l}\text { 1) Infections } \\
\text { 2) Mortality }\end{array}$ & $\begin{array}{l}\text { 1) data ND } \\
\text { 2) } 5.9 \% \text { vs. } 7.5 \%\end{array}$ & $\begin{array}{l}\text { 1) ns, data ND } \\
\text { 2) ns, data ND }\end{array}$ \\
\hline $\begin{array}{l}\text { Wallis et al. } \\
2002[32]\end{array}$ & $597 / 409$ (69) & $\begin{array}{l}\text { CABG } \pm \text { valve } \\
\text { surgery }\end{array}$ & $\begin{array}{l}\text { LD } 176 \\
\text { BCC } 175 \\
\text { PR } 158\end{array}$ & $\begin{array}{c}\text { LD } 3.9 \pm 3.9 \\
\text { BCC } 3.5 \pm 2.6 \\
\text { PR } 2.9 \pm 1.8\end{array}$ & $\begin{array}{l}\text { 1) Infections } \\
\text { 2) } 90 \text {-d mortality }\end{array}$ & $\begin{array}{l}\text { 1) } 11.1 \% \text { vs. } 17.7 \% \\
\text { 2) } 1.7 \% \text { vs. } 2.5 \%\end{array}$ & $\begin{array}{l}\text { 1) } 0.1 \\
\text { 2) } 0.2\end{array}$ \\
\hline $\begin{array}{l}\text { Bilgin et al. } \\
2004[33]\end{array}$ & $474 / 432(91)$ & $\begin{array}{c}\text { Valve } \\
\text { surgery } \pm \mathrm{CABG}\end{array}$ & $\begin{array}{c}\text { LD } 216 \\
\text { BCD } 216\end{array}$ & $\begin{array}{c}\text { LD } 6.2 \pm 7.1 \\
\text { BCD } 5.9 \pm 6.1\end{array}$ & $\begin{array}{l}\text { 1) Infections } \\
\text { 2) MODS } \\
\text { 3) Hospital mortality } \\
\text { 4) } 90 \text {-d mortality }\end{array}$ & $\begin{array}{l}\text { 1) } 22.6 \% \text { vs. } 31.6 \% \% \\
\text { 2) } 20.4 \% \text { vs. } 20.7 \% \\
\text { 3) } 5.5 \% \text { vs. } 10.1 \% \\
\text { 4) } 8.4 \% \text { vs. } 12.7 \%\end{array}$ & $\begin{array}{l}\text { 1) } 0.02 \\
\text { 2) } 0.98 \\
\text { 3) } 0.05 \\
\text { 4) } 0.16\end{array}$ \\
\hline $\begin{array}{l}\text { Connery et al. } \\
2005[34]\end{array}$ & $98 / 69(70)$ & Primary CABG & $\begin{array}{c}\text { LD } 38 \\
\text { BCC } 31\end{array}$ & $\begin{array}{c}\text { LD } 5.6 \pm 13 \\
\text { BCC } 5.6 \pm 10\end{array}$ & $\begin{array}{l}\text { 1) Infections } \\
\text { 2) } 30 \text {-d mortality }\end{array}$ & $\begin{array}{l}\text { 1) } 13.2 \text { vs. } 25.8 \% \\
\text { (PTI: } 0 \% \text { vs. } 12.9 \% \text { ) } \\
\text { 2) } 2.6 \% \text { vs. } 3.2 \%\end{array}$ & $\begin{array}{l}\text { 1) } 0.22 \\
\text { (PTI:0.048) } \\
\text { 2) } 1.0\end{array}$ \\
\hline $\begin{array}{l}\text { Boshkov et al. } \\
2006[36]^{\mathrm{a}}\end{array}$ & $1227 / 562(46)$ & $\begin{array}{c}\text { CABG } \\
\pm \text { valve surgery }\end{array}$ & $\begin{array}{c}\text { LD } 304 \\
\text { BCC } 258\end{array}$ & ND & $\begin{array}{l}\text { 1) Serious infections } \\
\text { 2) } 60-d \text { mortality }\end{array}$ & $\begin{array}{l}\text { 1) data ND } \\
\text { 2) } 4.9 \% \text { vs. } 9.7 \%\end{array}$ & $\begin{array}{l}\text { 1) ns, data ND } \\
\text { 2) } 0.36\end{array}$ \\
\hline
\end{tabular}

aAvailable only as abstract

bComparison of leukocyte-depleted and leukocyte-containing RBCs

LD: Leukodepleted RBCs; FF: fresh filtered RBCs; SF: stored filtered RBCs; BCD: buffy-coat-depleted RBCs; BCC: buffy-coat-containing; WBF: white blood cell

filtered; PR: plasma-reduced; ND: not documented; PTI: pulmonary tract infections; MODS: multiple organ dysfunction syndrome 
remain unknown. A predominant role of plasma transfusions in cardiac surgery outcome was reported by Ranucci et al. [54]. Other studies that focused on plasma transfusions reported inconsistent findings [55,56]. Moreover, some studies reported that platelet transfusions in cardiac surgery were not independently associated with mortality [57,58], while two studies found an association between platelet transfusions and mortality $[59,60]$. The role of plasma and platelet transfusions in cardiac surgery complications requires further investigation.

\section{Laboratory Effects of Allogeneic Leukocytes in Cardiac Surgery}

Pro- and anti-inflammatory mediators are released during and after cardiac surgery. Cytokine concentration imbalance can play a pivotal role in a balanced equilibrium after cardiac surgery. Cytokines are low molecular weight polypeptides produced by many cells, such as macrophages, monocytes, neutrophils, and platelets. They are divided into 2 groups: pro-inflammatory cytokines, such as interleukin-1 (IL-1), IL-2, IL-8, and IL-12, and anti-inflammatory cytokines, such as IL-4, IL-5, and IL-10. IL-6, on the other hand, has both pro-and anti-inflammatory properties $[61,62]$. In the early postoperative period an anti-inflammatory response is important for further limiting the post-surgical inflammatory response. Few studies have investigated the possible mechanisms of allogeneic leukocyte-containing blood products in cytokine balance. One study that included 24 burn trauma patients reported a decrease in IL-6 in patients that received leukocytecontaining RBC transfusions [63]. A larger cardiac surgery study noted an association between perioperative allogeneic RBC transfusions and postoperative increase in the concentration of bactericidal permeability increasing protein (BPI), an inflammatory mediator and marker of neutrophil activation, and IL-6 [64]. Nevertheless, none of these studies investigated the relationships between blood products, inflammatory mediators, and outcome.

Bilgin et al. reported that among the patients that developed infections or MODS, or died due to these complications, those that received leukocyte-containing RBCs had higher pro-inflammatory cytokine concentrations and those that received leukocytedepleted RBCs had lower concentrations of antiinflammatory cytokine IL-10 [65]. Patients in both arms of the study had low concentrations of IL-10 upon arrival to the ICU. The IL-6 concentration peaked higher and later in the group that received leukocyte-containing RBCs than in the group that received leukocyte-depleted RBCs. These findings indicate that leukocyte-containing blood transfusions amplify the inflammatory response, in addition to an ongoing systemic inflammatory response induced by cardiac surgery. This may lead to a more profound counteractive anti-inflammatory response and may explain increased susceptibility to postoperative infections.

\section{Inflammatory Response and Allogeneic Leukocytes in Cardiac Surgery}

During cardiac surgery blood is exposed to the extra-corporeal circuit, hypothermia, and ischemia/ reperfusion injury, and many inflammatory responses are activated. These responses lead to post-perfusion systemic inflammatory response syndrome (SIRS). SIRS is immediately counteracted by compensatory anti-inflammatory response syndrome (CARS) [66]. Severe SIRS causes a dormant state of cell metabolism, referred to as MODS; SIRS usually resolves with adequate supportive therapy and most patients recover. Nonetheless, severe SIRS can dominate CARS and progress to MODS, which may lead to mortality. Previous findings indicate that leukocyte-containing blood transfusions amplify inflammatory response in addition to the ongoing systemic inflammatory response induced by cardiac surgery. This may lead to a more profound counteractive anti-inflammatory response, and may explain increased susceptibility to postoperative infections. We think that leukocyte-containing RBC transfusions in patients with an activated inflammatory response further imbalances the postoperative SIRS-CARS equilibrium that is initially in favor of SIRS [67].

\section{New Opportunities for Future Cardiac Surgery Research}

Patients undergoing cardiac surgery are at risk for bleeding because of thrombocytopenia secondary to hemodilution, platelet dysfunction, and consumption of platelets in the extracorporeal circuit. To reduce the risk of bleeding several pharmacological agents are used during and after surgery [68]. On the other hand, to prevent thrombosis anticoagulants are administered intra-operatively, although this cannot completely prevent thrombin formation [69]. There is evidence that the inflammatory response and pro-inflammatory cytokines can lead to activation of the coagulation system and down-regulate 
anticoagulant systems [70]. Activation of coagulation factors can in turn activate inflammation, which may contribute to the development of infections and microvascular thrombi [71]. Both thrombi and infection play a role in the development of MODS and may lead to death [72]. It was recently reported that leukocyte-containing RBCs contain activated platelets that interact with leukocytes, preceding leukocyte apoptosis and death, subsequently producing microparticles with procoagulant activity [73]. It was recently suggested that transfusion of blood prod- ucts could affect the development of thrombosis in high-risk patients [74,75]. The relationship between transfusion and thrombosis requires further detailed investigation.

Any allogeneic RBC transfusion during an already existing inflammatory cascade can be inappropriately timed and can induce a second-hit response. The presence of leukocytes in blood products increases the production and release of proinflammatory cytokines in the recipient, which can cause SIRS via both activation of the coagulation system

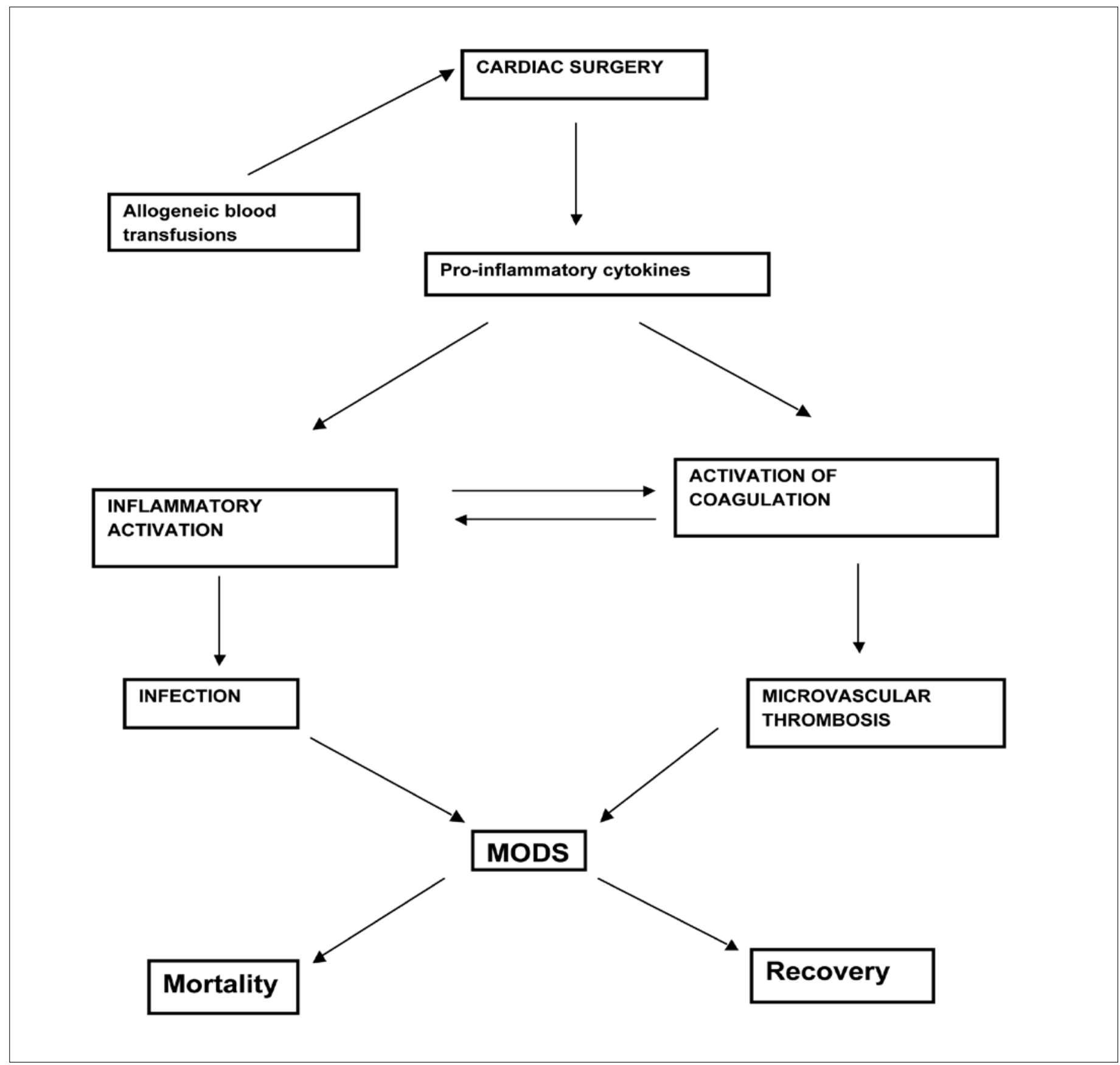

Figure 1. The possible relationship between allogeneic blood transfusions, and inflammation and coagulation 
and the inflammatory response. This second-hit response induced by allogeneic leukocytes may exacerbate MODS (in combination with infections or microvascular thrombosis) and could result in death (Figure 1). Other factors, such as plasma and platelet transfusions (due to activation or storage lesions) and (possible) activation of the coagulation system, may play more important roles in the development of transfusion-associated complications. Thus, many residual questions need to be answered in the future, posing a challenge for new research in transfusion medicine.

\section{Conclusion}

Worldwide, millions of patients receive blood transfusions. Allogeneic leukocyte-containing RBC transfusions may have immunomodulatory effects that are presumed harmful to recurrence of cancer and to resistance of postoperative infection. This concept informed RTCs on various clinical conditions in different fields of medicine; however, important questions remain as to the nature and magnitude of the clinical benefits and complications ascribed to TRIM, its mechanism, and the putative causal factors in allogeneic blood components. Only RCTs on cardiac surgery reported a beneficial (costsaving) effect of leukodepleted RBC transfusion. Conducting new RCTs on the effects of leukocytecontaining RBCs in countries that implemented universal leukoreduction of blood products is not possible. Based on available data, in countries that have not yet implemented universal leukoreduction the transfusion of leukodepleted RBCs is recommended for cardiac surgery [23]. Or, if possible, new RCTs should be performed in these countries, which could help answer the many remaining questions.

\section{Conflict of interest statement}

The authors of this paper have no conflicts of interest, including specific financial interests, relationships, and/or affiliations relevant to the subject matter or materials included.

\section{References}

1. Klein HG. How safe is blood, really? Biologicals 2010; 38:100-4. [CrossRef]

2. Snyder-Ramos SA, Mohnle P, Weng YS, Bottiger BW, Kulier A, Levin J, Mangano DT; Investigators of the Multicenter Study of Perioperative Ischemia; MCSPI Research Group. The ongoing variability in blood transfusion practices in cardiac surgery. Transfusion 2008; 48:1284-99. [CrossRef]
3. Stover EP, Siegel LC, Parks R, Levin J, Body SC, Maddi R, D'Ambra MN, Mangano DT, Spiess BD. Variability in transfusion practice for coronary artery bypass surgery despite national consensus guidelines. Anesthesiology 1998;88:327-33.

4. Goodnough LT, Johnston MFM, Toy PTCY. The variability of transfusion practice in coronary artery bypass surgery. JAMA 1991;265:86-90.

5. Carson JL, Kuriyan M. What should trigger a transfusion? Transfusion 2010;50:2073-5.

6. Hebert PC, Wells G, Blajchman MA, Marshall J, Martin C, Pagliarello G, Tweeddale M, Schweitzer I, Yetisir E, on behalf of the Canadian TRIC investigators. A multicenter randomised, controlled clinical trial of transfusion requirements in critical care. New Engl J Med 1999;340:409-17.

7. Crosby E. Re-evalutaing the transfusion trigger: how low is safe? Am J Ther 2002;9:411-6.

8. Hajjar LA, Vincent JL, Galas FR, Nakamura RE, Silva CM, Santos MH, Fukushima J, Kalil Filho R, Sierra DB, Lopes NH, Mauad T, Roquim AC, Sundin MR, Leão WC, Almeida JP, Pomerantzeff PM, Dallan LO, Jatene FB, Stolf NA, Auler JO Jr. Transfusion requirements after cardiac surgery. JAMA 2010; 304:1559-67. [CrossRef]

9. Vincent JL, Sakr Y, Sprung C, Harboe S, Damas P; on behalf of the SOAP Investigators. Are blood transfusions associated with greater mortality rates? Results of the Sepsis Occurrence in Acutely Ill Patients study. Anesthesiology 2008;108:31-9.

10. Sakr Y, Lobo S, Knuepfer S, Esser E, Bauer M, Settmacher U, Barz D, Reinhart K. Anemia and blood transfusion in a surgical intensive care unit. Crit Care 2010;14:R92.

11. Ho J, Sibbald WJ, Chin-Yee IH. Effects of storage on efficacy of red cell transfusion: when is it not safe? Crit Care Med 2003;31:S687-97.

12. Tinmouth A, Fergusson D, Yee IC, Hébert PC; on behalf of the ABLE Investigators. Clinical consequences of red cell storage. Transfusion 2006; 46:2014-27. [CrossRef]

13. Vamvakas EC, Carven JH. Transfusion and postoperative pneumonia in coronary artery bypass graft surgery: effect of the length of storage of transfused red cells. Transfusion 1999;39:701-10.

14. Yap CH, Lau L, Krishnaswamy M, Gaskell M, Yii M. Age of transfused red cells and early outcomes after cardiac surgery. Ann Thorac Surg 2008; 86:554-9. [CrossRef]

15. Hebert PC, Chin-Yee I, Fergusson D, Blajchman M, Martineau R, Clinch J, Olberg B. A pilot trial evaluating the clinical effects of prolonged storage of red cells. Anesth Analg 2005;100:1433-8.

16. van de Watering $L$, Lorinser J, Versteegh M, Westendord $\mathrm{R}$, Brand A. Effects of storage time of red blood cell transfusions on the prognosis of coronary artery bypass graft patients. Transfusion 2006;46:1712-8.

17. van Straten AH, Soliman Hamad MA, van Zundert AA, Martens EJ, ter Woorst JF, de Wolf AM, Scharnhorst V. Effect of duration of red blood cell storage on early and late mortality after coronary artery bypass grafting. J Thorac Cardiovasc Surg. 2011;141:231-7.

18. Koch CG, Li L, Sessler DI, Figueroa P, Hoeltge GA, Mihaljevic T, Blackstone EH. Duration of red-cell storage and compliactions after cardiac surgery. N Engl J Med 2008; 358:1229-39. [CrossRef] 
19. Benjamin RJ, Dodd RY. Red-cell storage and complications of cardiac surgery. New Engl J Med 2008;358:2840-1.

20. van de Watering L. Red cell storage and prognosis. Vox Sang 2011;100:36-45.

21. Opelz G, Sengar DDS, Mickey MR, et al. Effect of blood transfusions on subsequent kidney transplants. Transplant Proc 1973; 5:253-9. [CrossRef]

22. Gantt CL. Red blood cells for cancer patients. Lancet 1981;2:363.

23. Vamvakas EC, Blajchman MA. Transfusion-related immunomodulation (TRIM): an update. Blood reviews 2007; $21: 327-48$. [CrossRef]

24. Houbiers JGA, Brand A, van de Watering LMG, Hermans J, Verwey PI, Bijnen AB, van de Velde CHJ. A randomized controlled trial comparing the prognosis of colorectal cancer patients transfused with either leukocyte depleted or buffy coat depleted blood. Lancet 1994;344:573-8.

25. van de Watering LM, Brand A, Houbiers JG, Klein Kranenbarg WM, Hermans J, van de Velde C; Cancer Recurrence and Blood transfusion study group. Perioperative blood transfusions, with or without allogeneic leucocytes, relate to survival, not to cancer recurrence. Br J Surg. 2001;88:267-72.

26. Skanberg J, Lundholm K, Haglind H. Effects of blood transfusion with leucocyte depletion on length of hospital stay, respiratory assistance and survival after curative surgery for colorectal cancer. Acta Oncologica 2007;46:1123-30.

27. Chelemer SB, Prato S, Cox PM, O'Connor GT, Morton JR. Association of bacterial infection and red blood cell transfusion after CABG. Ann Thorac Surg 2002;73:138-42.

28. Leal-Noval SR, Rincon-Ferrari MD, Garcia-Curiel A, Herruzo-Avilés A, Camacho-Larana P, GarnachoMontero J, Amaya-Villar R. Transfusion of blood components and postoperative infection in patients undergoing cardiac surgery. Chest 2001;119:1461-8.

29. Koch CG, Li L, Duncan AI, Mihaljevic T, Cosgrove DM, Loop FD, Starr NJ, Blackstone EH. Morbidity and mortality risk associated with red blood cell and bloodcomponent transfusion in isolated coronary artery bypass grafting. Crit Care Med 2006;34:1608-16.

30. Despotis G, Eby, C, Lublin DM. A review of transfusion risks and optimal management of perioperative bleeding with cardiac surgery. Transfusion 2008;48:2S-30S.

31. van de Watering LM, Hermans J, Houbiers JG, van den Broek PJ, Bouter H, Boer F, Harvey MS, Huysmans HA, Brand A. Beneficial effects of leukocyte depletion of transfused blood on postoperative complications in patients undergoing cardiac surgery: a randomized clinical trial. Circulation 1998;97:562-8.

32. Wallis JP, Chapman CE, Orr KE, Clark SC, Forty JR. Effect of WBC reduction of transfused RBCs on postoperative infection rates in cardiac surgery. Transfusion 2002;42:1127-34.

33. Bilgin YM, van de Watering LM, Eijsman L, Versteegh MIM, Brand R, van Oers MHJ,Brand A. Double-blind, randomized controlled trial on the effect of leukocytedepleted erythrocyte transfusions in cardiac valve surgery. Circulation 2004;109:2755-60.
34. Connery CP, Toumpoulis IK, Anagnostopoulis CE, Hillei Z, Rahman FG, Katritsis D, Swistel DG. Does leukofiltration reduce pulmonary infections in CABG patients? A prospective, randomised study with early results and mid-term survival. Acta Cardiol 2005;60:285-93.

35. Bracey AW, Radovancevic R, Nussmeier NA. Leukocytedepleted blood in open-heart surgery patients: effects on outcome. Transfusion 2002;42(Suppl):5S (Abstract).

36. Boshkov LK, Chien G, VanWinkle D, Furnary AP, Wu Y, Grunkemeirer GL, Morris CD. Prestorage leukoreduction of transfused packed red cells is associated with significant ongoing 1-12 month survival benefit cardiac surgery patients. Blood 2006;108:578.

37. Vamvakas EC. White-blood-cell-containing alloegenic blood transfusions and postoperative infection and mortality: an updated meta-analysis. Vox Sang 2007;92:224-32.

38. Bilgin YM, van de Watering LMG, Eijsman L, Versteegh MIM, van Oers MHJ, Brand A. Is increased mortality associated with postoperative infections after leukocytes containing red blood cell transfusions in cardiac surgery? Transf Med 2007;17:304-11.

39. Engoren M, Habib RH, Hadaway J, Zacharias A, Schwann TA, Riordan CJ, Durham SJ, Shah A. The effect on long-term survival of erythrocyte transfusion given for cardiac valve operations. Ann Thorac Surg 2009;88:95-100.

40. Jensen LS, Andersen AJ, Christiansen PM, Hokland P, Juhl CO, Madsen G, Mortensen J, Moller-Nielsen C, Hanberg-Sorensen F, Hokland M. Postoperative infection and natural killer cell function following blood transfusion in patients undergoing elective colorectal surgery. Br J Surg 1992;79:513-6.

41. Houbiers JG, Brand A, van de Watering LM, Hermans J, Verwey PJ, Bijnen AB, Pahlplatz P, Eeftinck Schattenkerk M, Wobbes T, de Vries JE. Randomised controlled trial comparing transfusion of leucocyte-depleted or buffycoat-depleted blood in surgery for colorectal cancer. Lancet. 1994;344:573-8.

42. Jensen LS, Kissmeyer-Nielsen P, Wolff B, Qvist N. Randomized comparison of leucocyte-depleted versus buffy-coat poor blood transfusion and complications after colorectal surgey. Lancet 1996;34:841-5.

43. Tartter P, Mohandes K, Azar P, Endres J, Kaplan J, Spivack M. Randomized trial comparing packed red blood cell transfusion with and without leukocyte depletion for gastrointestinal surgey. Am J Surg 1998;176:462-6.

44. Titlestad IL, Ebbesen LS, Ainsworth AP, Lillevang ST, Qvist N, Georgsen J. Leukocyte-depletion of blood components does not significantly reduce the risk of infectious complications. Results of a double-blinded, randomised study. Int J Colorectal Disease 2001;16:147-53.

45. van Hilten JA, van de Watering LMG, van de Velde CHJ, Kievit J, Brand R, van den Hout WB, Geelkerken RH, Roumen RMH, Wesselink RMJ, Koopman-van Gemert AWMM, Koning J, Brand A. Effects of transfusion with red cells filtered to remove leukocytes: randomised controlled trial in patients undergoing major surgery. BMJ 2004;328:1281-4. 
46. Nathens AB, Nester TA, Rubenfeld GD, Nirula R, Gernsheimer TB. The effects of leukoreduced blood transfusion on infection risk following injury: a randomized controlled trial. Shock 2006;26:342-7.

47. Blumberg $\mathrm{N}$, Zhao $\mathrm{H}$, Wang $\mathrm{H}$, Messing S, Heal JM, Lyman GH. The intention-to-treat principle in clinical trials and meta-analysis of leukoreduced blood transfusions in surgical patients. Transfusion 2007;47:573-81.

48. Jensen LS, Grunnet N, Hanberg-Sorensen F, Jorgensen J. Cost-effectiveness of blood transfusion and white cell reduction in elective colorectal surgery. Transfusion 1995;35:719-22.

49. Blumberg N, Heal JM, Kirkley SA, DiPersio JF, Rapoport AP, Rowe JM. Leukodepleted-ABO-identical blood components in the treatment of hematologic malignancies: a cost analysis. Am J Hematology 1995;48:108-15.

50. Postma MJ, van de Watering LMG, de Vries R, Versmoren D, van Hulst M, Tobi $\mathrm{H}$, van der Poel CL, Brand A. Cost-effectiveness of leucocyte depletion of red-cell transfusions for patients undergoing cardiac surgery. Vox Sang 2003;84:65-7.

51. van Hulst M, Bilgin YM, van de Watering LMG, de Vries R, van Oers MHJ, Brand A, Postma MJ. Cost-effectiveness of leucocyte-depleted erythrocyte transfusion in cardiac valve surgery. Transf Med 2005;15:209-17.

52. Hebert PC, Fergusson D, Blajchman MA, Wells GA, Kmetic A, Coyle D, Heddle N, Germain M, Goldman M, Toye B, Schweitzer I, vanWalraven C, Devine D, Sher GD, on behalf of the Leukoreduction Study Investigators. Clinical outcomes following institution of the Canadian universal leukoreduction program for red blood cell transfusions. JAMA 2003;289:1941-9.

53. Silliman CC. The two-event model of TRALI. Crit Care Med 2006; 34:S124-31. [CrossRef]

54. Ranucci M, Pazzaglia A, Bianchini C, Bozzetti G, Isgro G. Body size, gender, and transfusions as determinants of outcome after coronary operations. Ann Thorac Surg 2008;85:481-7.

55. Banbury MK, Brizzio ME, Rajeswaran J, Lytle BW, Blackstone EH. Transfusion increases the risk of postoperative infection after cardiac surgery. J Am Coll Surg 2006;202:131-8.

56. Sreeram GM, Welsby IJ, Sharma AD, Philips-Bute B, Smith PK, Slaughter TF. Infectious complications after cardiac surgery: lack of association with FFP or platelet transfusions. J Cardiothoracic Vasc Anesthesia 2005;19:430-4.

57. Karkouti K, Wijeysundera DN, Yau TM, Callum JL, Meineri M, Wasowicz M, McCluskey SA, Beattie WS. Platelet transfusions are not associated with increased morbidity or mortality in cardiac surgery. Can J Anesth 2006;53:279-87.

58. McGrath T, Koch CG, Xu M, Li L, Mihaljevic T, Figueroa P, Blackstone EH. Platelet transfusion in cardiac surgery does not confer increased risk for adverse morbid outcomes. Ann Thorac Surg 2008;86:543-53.

59. Spiess BD, Royston D, Levy JH, Fitch J, Dietrich W, Body S, Murkin J, Nadel A. Platelet transfusions during CABG surgery are associated with serious adverse outcomes. Transfusion 2004;44:1143-8.
60. Mangano DT, for the multicenter study of perioperative ischemia research group. Aspirin and mortality from coronary bypass surgery. N Engl J Med 2002;347:1309-17.

61. Dinarello CA. Proinflammatory cytokines. Chest 2000;118:503-8.

62. Opal SM, DePalo VA. Anti-inflammatory cytokines. Chest 2000;117:1162-72.

63. Nielsen HJ, Hammer JH, Krarup AL, Nielsen LM, Reimert CM, Pedersen AN, Dybkjaer E, Partoft S, Alsbjørn B. Prestorage leukocyte filtration may reduce leukocytederived bioactive substances accumulation in patients operated for burn trauma. Burns 1999;25:162-70.

64. Fransen E, Maessen J, Dentener M, Senden N, Buurman W. Impact of blood transfusions on inflammatory mediator release in patients undergoing cardiac surgery. Chest 1999;116:1233-9.

65. Bilgin YM, van de Watering LMG, MIM Versteegh, MHJ van Oers, A Brand. The effects of allogeneic leukocytes in blood transfusions during cardiac surgery on inflammatory mediators and postoperative complications. Crit Care Med 2010;38:546-52.

66. Bone RC. Sepsis, SIRS and CARS. Crit Care Med 1996;24:1125-8.

67. Bilgin YM, Brand A. Transfusion-related immunomodulation: a second hit in an inflammatory cascade? Vox Sang 2008;95:261-71.

68. Levi M, Cromheecke ME, de Jonge E, Prins MH, de Mol BJ, Briet E, Buller HR. Pharmacological strategies to decrease excessive blood loss in cardiac surgery: a meta-analysis of clinically relevant endpoints. Lancet 1999;354:1940-7.

69. Paparella D, Galeone A, Venneri MT, Coviello M, Scrascia G, Marraudino N, Quaranta M, de Luca Tupputi Schinosa L, Brister SJ. Activation of the coagulation system during coronary artery bypass grafting: comparison between on-pump and off-pump techniques. J Thorac Cardiovasc Surg 2006;131:290-7.

70. van der Poll T, Levi M, Hack CE, ten Cate $H$, van Deventer SJ, Eerenberg AJ, de Groot ER, Jansen J, Gallati H, Büller HR. Elimination of IL-6 attenuates coagulation activation in experimental endotoxemia in chimpanzees. J Exp Med 1994;179:1253-9.

71. Levi M, Keller TT, van Gorp E, ten Cate H. Infection and inflammation and the coagulation system. Cardiovasc Res 2003;60:23-39.

72. Gando S. Microvascular thrombosis and multiple organ dysfunction syndrome. Crit Care Med 2010;38(Suppl): S35-42.

73. Keating FK, Butenas S, Fung MK, Schneider DJ. Plateletwhite blood cell (WBC) interaction, WBC apoptosis and procoagulant activity in stored red blood cells. Transfusion 2010;51:1086-95.

74. Khorana AA, Francis CW, Blumberg N, Culakova E, Refaai MA, Lyman GH. Blood transfusions, thrombosis and mortality in hospitalized patients with cancer. Arch Intern Med 2008;168:2377-81.

75. Heal JM, Phipps RP, Blumberg N. One big unhappy family: transfusion alloimmunization, thrombosis, and immune modulation/inflammation. Transfusion 2009;49:1032-6. 